\title{
Physico-Chemical Characterization of Tropical Wood Species for Use and Production of Grilling Planks
}

\author{
Ulysses Harley Guedes ${ }^{a}$, Maria Fátima do Nascimento ${ }^{b}$, Diogo Aparecido Lopes Silva ${ }^{c}$,

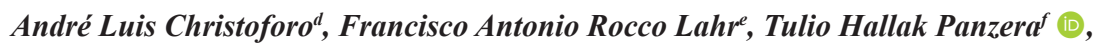 \\ Vinicius Borges de Moura Aquino * (D), Raísse Layane de Paula Saraiva ${ }^{g}$ \\ ${ }^{a}$ Universidade de São Paulo, Departamento de Ciências e Engenharia de Materiais, \\ Av. Trabalhador São Carlense, 13566-590, São Carlos, SP, Brasil. \\ ${ }^{b}$ Universidade de São Paulo, Laboratório de Madeiras e Estruturas de Madeira, \\ Av. Trabalhador São Carlense, 13566-590, São Carlos, SP, Brasil. \\ 'Universidade Federal de São Carlos, Departamento de Engenharia de Produção, \\ Rodovia João Leme dos Santos (SP-264), Km 110, 18052-780, Sorocaba, SP, Brasil. \\ ${ }^{d}$ Universidade Federal de São Carlos, Departamento de Engenharia Civil, \\ Rodovia Washington Luís, 13565-905, São Carlos, SP, Brasil. \\ eUniversidade de São Paulo, Departamento de Engenharia de Estruturas, \\ Av. Trabalhador São Carlense, 13566-590, São Carlos, SP, Brasil. \\ ${ }^{f}$ Universidade Federal de São João del-Rei, Departamento de Engenharia Mecânica, \\ Praça Frei Orlando, 170, 36307-352, São João del-Rei, MG, Brasil. \\ ' Universidade Federal do Sul e Sudeste do Pará, Instituto de Engenharia do Araguaia, \\ Rua Geraldo Ramalho, 68560-000, Santana do Araguaia, PA, Brasil.
}

Received: April 29, 2021; Revised: August 19, 2021; Accepted: September 23, 2021

The objective of this research is to evaluate the possibility of use of tropical hardwood species (Amburana cearensis and Cedrella fissilis) for grilling plank production. Physical, chemical and organoleptic properties were evaluated and compared with properties of a well-used wood specie for grilling plank across Europe and USA, Western Red Cedar (Thuja plicata). For chemical analysis, three techniques were used: hydro distillation, soxhlet and head space. Normality test and analysis of variance (ANOVA) were used for the comparison between Thuja plicata and tropical hardwoods. The results of organoleptic, chemical and statistical analysis demonstrated the possibility of use of Amburana cearensis and Cedrella fissilis on grilling plank production, with no volatile compound present in these species being toxic, low apparent density and Nerolidol presence, chemical compound used as flavoring agent, enabling their use as grilling planks.

Keywords: grilling plank, apparent density, Brazilian tropical hardwood, chemical analysis.

\section{Introduction}

For many ages, wood has been used for several purposes on human life, since agricultural implements, shelters and tools. Also, it is used nowadays for furniture, civil construction for structural and non-structural purpose, paper and pulp industry, sports equipment and food industry ${ }^{1-3}$.

For an appropriate use of wood on food industry, flavor and ingredients industry have developed many advances on flavors, smells and enzymes in order to develop new products and new production process ${ }^{3-6}$.

Considering food industry, one of the most used process is the conventional smoking. It is characterized by food exposure to smoke and their derivatives to conserve food. In present time, smoking process is highlighted due the organoleptic characteristic inherent to the smoking process, such as flavor, color and smell?.

*e-mail: aquino.vini@hotmail.com
Another form to smoke food is using grilling planks. In this process, food is in contact with wood planks, adding to the food complex flavors and humid texture. Smoking, in this case, do not aim to improve food lifetime, but improve their taste and smell at their consumption. Grilling plank works as a smoker as the porous surface of the wood absorbs moisture and then, when taken to a barbecue or heated oven, releases it together with an aromatic smoke. Food is cooked slowly and, as a result, becomes tastier, has a pleasant aroma and is less susceptible to loss of nutrients ${ }^{8}$.

The use of grilling planks has become a popular method to smoke several meals and finalize many dishes, such salmon, fish and vegetables, not cooked directly on fire. Native americans from Pacific coast realized that dishes cooked on Western Red Cedar (Thuja plicata) wood planks were tastier, soft flavor and not burned when consumed. Also, on 
Europe, it has become very used on restaurants considering the benefits for flavor and smell 7,8 .

However, the existence of the compound thujone, a terpene and related to a menthol, which occurs naturally in plants, trees (bark and leaves), in the essential oil of Thuja plicata (Western red cedar), cedar white and other herbs such as Arthemisia absinthium (wormwood). In extremely high doses, thujone is dangerous and can cause seizures. Thujone-induced seizures are epileptiform in character and are preceded by general vasodilation, a drop in artery pressure, decreasing heart rate and increasing respiratory amplitude 9 .

Brazil owns the largest number of wood species in the world (8715 wood species) and a large vegetal cover, being $52 \%$ of Brazilian territory ${ }^{10,11}$. This amount of wood species and vegetal cover displays a unique diversity of aromatic trees from hardwoods group, such as Anacardiaceae, Anonaceae, Fabaceae, Lamiaceae, Araceae, Meliaceae families. For sotfwoods, the families Cupressaceae, Abietaceae and Betulaceae are considered aromatic plants. Considering the diversity of chemical components present on these families, it is eased the selection of wood species with potential for grilling planks production ${ }^{12,13}$.

Aiming to contribute to the development of food industry and the use of grilling planks made of Brazilian native wood species, the present research presents the physical and chemical characterization of Amburana cerarensis Smith. and Cedrella fissilis Vell. wood species and compare their properties with Thuja plicata wood specie, one of the pioneer wood specie used to produce grilling planks in the world.

\section{Materials and Methods}

The wood species Thuja plicata, Amburana cearensis and Cedrella fissilis were harvested and stored in homogeneous batches on equilibrium moisture of $12 \%$, following the disposed on Brazilian Standard ABNT NBR $7190^{14}$. The batches were deposited on Wood and Timber Structures Laboratory (LaMEM), University of São Paulo, São Carlos, São Paulo, Brazil.

For the analysis of organoleptic properties of wood species, sensory analysis were performed to check smell, color, taste, grain and texture, following the parameters described on the literature ${ }^{15}$. For wood smell evaluation, main characteristic to be analyzed, three steps were performed: (i) in natura, (ii) after immersion on cold water for 60 minutes; (iii) during use on heat source $\left(190^{\circ} \mathrm{C}\right)$, identifying smell changes as with their use as grilling planks. Five LaMEM employees of male sex and ages ranging between 30 and 60 years, qualified the smell of each specie using the hedonic scale: bad, poor, fair, good or excellent. Figure 1 presents the heat source used.

For evaluation of apparent density $\left(\rho_{\text {ap }}\right)$ and the measure of contact angle and surface angle by the sessile drop method followed the disposed on the Brazilian Standard ABNT NBR 7190 , using specimens of $5 \mathrm{~cm} \times 3 \mathrm{~cm} \times 2 \mathrm{~cm}$, with the major dimension on the longitudinal direction of the fibers. For each test, 12 specimens were used for each wood specie.

For sessile drop method, it was used a KSV Cam 200 goniometer, which photographs the drops immediately after contact with the sample surface. The pattern used for time lapse between photographs: (i) in the interval between 0 and 5 seconds, 50 photos, one photo every $48 \mathrm{~ms}$ and (ii) in the interval 0 to 30 seconds, one photo every second. The $3 \mu \mathrm{l}$ volume was standardized for all solvent drops used on the wood surface. The solvents used were water, diiodomethane, formamide and ethylene glycol. Using the KSV contact angle measurement system program, the wettability graph was produced and the $0,5 \mathrm{~s}$ time was defined as the standard for calculating the contact angle with the surface of each sample.

For chemical analysis, the samples of wood were obtained according TAPPI Standard ${ }^{16,17}$. The wood was crushed mill equipment type Willey SL-31 to reach small particles passing a 30 mesh. The total extractive were evaluated by standard TAPPI $204 \mathrm{~cm}-97^{16}$, checking the volume of extractives on the samples. These samples were extracted in two phases in a soxhlet with a mix hexane/ethanol for 8 hours $(1: 1 \mathrm{v} / \mathrm{v})$; water for 8 hours and boiling distilled water for 30 minutes. After extractives remove, the samples were washed with distilled water and dried in oven at $100^{\circ} \mathrm{C} \pm 2{ }^{\circ} \mathrm{C}$ for 24 hours. The extractive content was calculated by mass difference. The resulting extractive-free wood was used to determine Klason lignin content by modified Klason method ${ }^{18}$, by the sum of insoluble and soluble lignin. The holocellulose

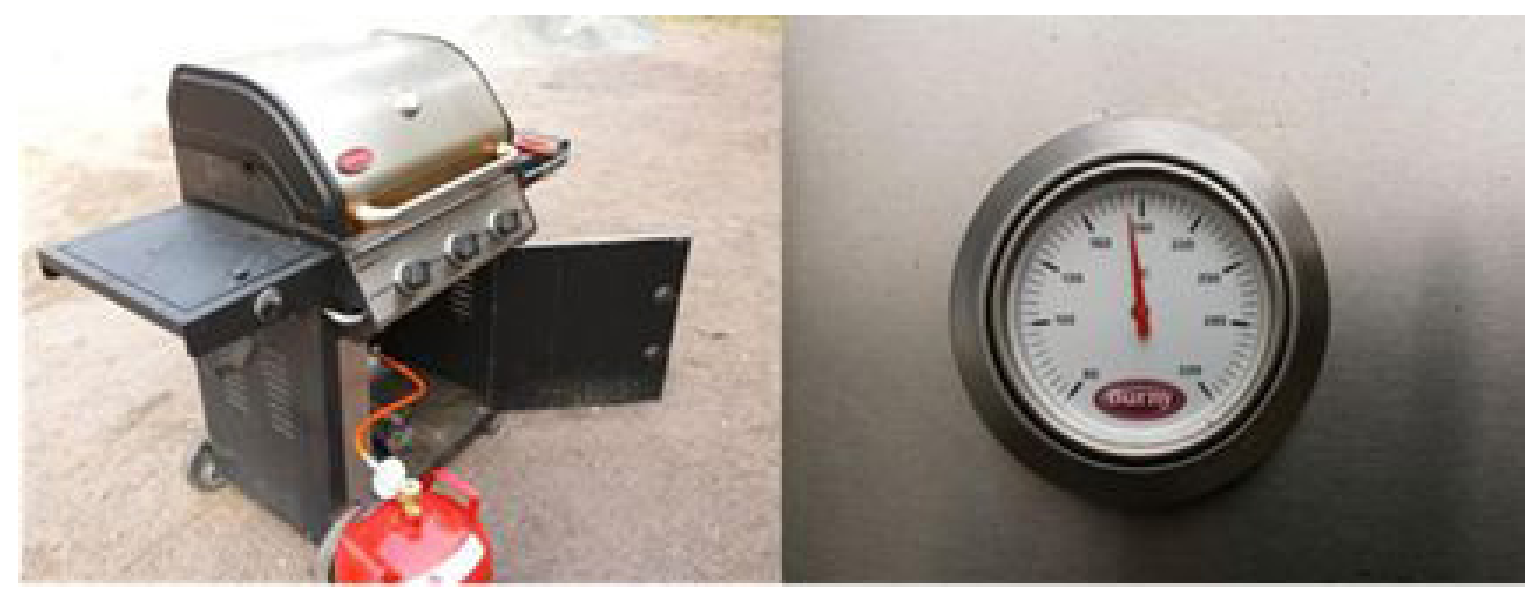

Figure 1. Heat source used for sensory analysis. 
content was determined by difference between lignin content and extractive-free wood mass ${ }^{19}$. Figure 2 illustrates the soxhlet extractor.

The ash content of the wood was obtained after calcination of the crucible. The material resulting from the filtration of the soluble lignin was taken to the oven for drying. 1,00 g of the sample was removed, which was crushed, dried and placed in a crucible, the mass of which was disregarded for calculation purposes. The crucible with the sample was subjected to calcination, exposing the material to $525^{\circ} \mathrm{C}$ in a muffle furnace, for the period of 4 hours, with a heating rate of $100{ }^{\circ} \mathrm{C} \cdot \mathrm{h}^{-1}$. The calculation of the ash content of the wood was determined by the amount of inorganic material in the sample after its calcination, that is, complete burning of the material. To calculate the percentage of ash in the material, the quotient between the mass of the residual material and the initially dry mass is made, multiplying the result by 100 .

Also, for chemical composition analysis by gas chromatography, three techniques were used: hydro distillation, soxhlet and head space. For the extraction of essential oil from wood species, hydro distillation was performed, using a graduated Clevenger apparatus protected by aluminum foil. $20 \mathrm{~g}$ dry wood of each species were used, ground to 40 mesh weight, and $500 \mathrm{ml}$ of distilled water.

The collection of essential oil extracted from each species was performed after 2.5 hours of boiling, using a graduated pipette. After collecting the samples, they were placed in hermetically sealed tubes, protected by aluminum foil and stored in a refrigerated place. The extractions were carried out in triplicates by species. The extracted essential oils were analyzed by GC-MS (Shimadzu gas chromatograph GC 2010AF Plus with TQ8040 Sequential Mass Spectrometer detector), with capillary column Rtx- $5 \mathrm{~ms} 30 \mathrm{~m}$ x $0.25 \mathrm{~mm}$ x $0.25 \mu \mathrm{m}$ RESTEK. The method used was heating rates from $40{ }^{\circ} \mathrm{C}$ to $120^{\circ} \mathrm{C}$, at a rate of $15^{\circ} \mathrm{C} / \mathrm{min}$, and from $125^{\circ} \mathrm{C}$ to $160{ }^{\circ} \mathrm{C}$, at a rate of $1{ }^{\circ} \mathrm{C} / \mathrm{min}$, remaining at $160{ }^{\circ} \mathrm{C}$ for 2 minutes.

Soxhlet extraction was carried out after establishing what would be the best solvent for the extraction of the species' essential oil. In the first stage, a mix of the five wood species was prepared with $30 \mathrm{~g}$ dry of each species

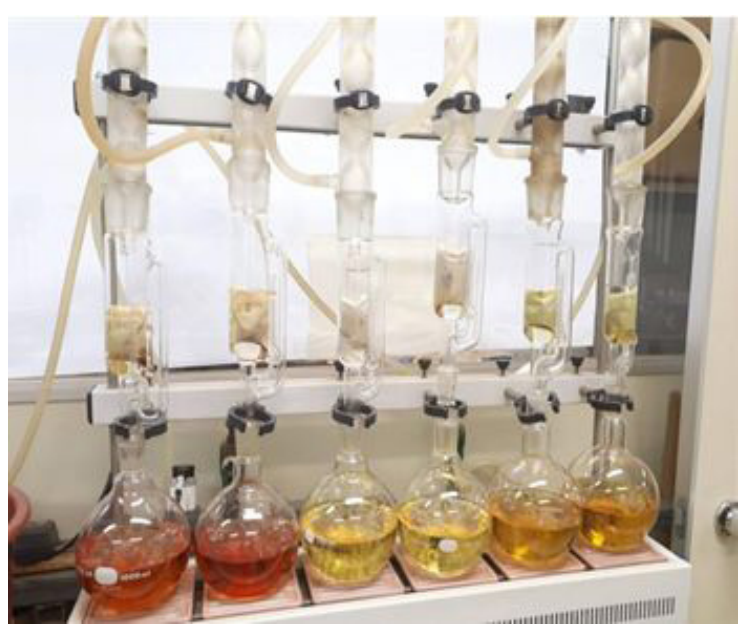

Figure 2. Soxhlet extractor. and mixed uniformly for extraction. For extraction, three usual solvents were chosen: ether, ethyl acetate and ethanol. Each extraction was performed in a soxhlet extraction apparatus with a $500 \mathrm{ml}$ flat-bottomed flask, using $10 \mathrm{~g}$ of the species mix, wrapped in filter paper, with $150 \mathrm{ml}$ of the respective extraction solvent. After 4 hours of extraction, the extract was removed and the solvent was removed under reduced pressure. The flat-bottomed flasks were placed in the chapel to reduce the solvent and the samples were then transferred to capped flasks and sealed. The extracts were analyzed by GC-MS (Shimadzu gas chromatographic GC 2010AF Plus with TQ8040 Sequential Mass Spectrometer detector), With capillary column Rtx-5ms $30 \mathrm{~m}$ x $0.25 \mathrm{~mm}$ x $0.25 \mu \mathrm{m}$; RESTEK Split mode 10. Figure 3 shows the gas chromatographic detector.

For head space analysis, it was initially necessary to carry out exploratory tests to define which parameters would be used for the best extraction. The tested parameters were: variation of the sample mass $(250 \mathrm{mg}$ and $500 \mathrm{mg}$ ), extraction time (20 minutes and 40 minutes), variation of heating temperature $\left(60^{\circ} \mathrm{C}\right.$ and $80^{\circ} \mathrm{C}$ ), wet sample (addition of $200 \mu \mathrm{l}$ of ultra-pure water) and dry sample. The extracts were analyzed by GC-MS (Shimadzu gas chromatographic GC 2010AF Plus with TQ8040 Sequential Mass Spectrometer detector), With capillary column Rtx-5ms $30 \mathrm{~m}$ x $0.25 \mathrm{~mm}$ x $0.25 \mu \mathrm{m}$; RESTEK Split mode 10 .

After qualitative exploratory analysis by GC-MS, the extraction method to be used in order to obtain a broader chemical profile of volatile compounds was defined. Extraction was performed with $250 \mathrm{mg}$ of sample moistened with $200 \mu \mathrm{l}$ of ultra-pure water, for 30 minutes, under constant agitation at $80^{\circ} \mathrm{C}$. Then, $1000 \mu \mathrm{l}$ of the volatile compounds were analyzed by GC-MS (Shimadzu GC 2010AF Plus gas chromatograph with Sequential Mass Spectrometer TQ8030 detector), with heating rate from $40{ }^{\circ} \mathrm{C}$ to $120^{\circ} \mathrm{C}$, at a rate of $15^{\circ} \mathrm{C} / \mathrm{min}$, and from $125^{\circ} \mathrm{C}$ to $160^{\circ} \mathrm{C}$, at a rate of $1{ }^{\circ} \mathrm{C} / \mathrm{min}$, remaining at $160^{\circ} \mathrm{C}$ for 2 minutes, capillary column Rtx-5ms 30 mx 0.25 mm x 0.25 um; RESTEK.

Chemical analysis was well decribed above in order to enhance the comprehension of fully chemical characterization of wood species. Also, if in a barbecue test there was wood carbonization, it could be explained by the low ash content.

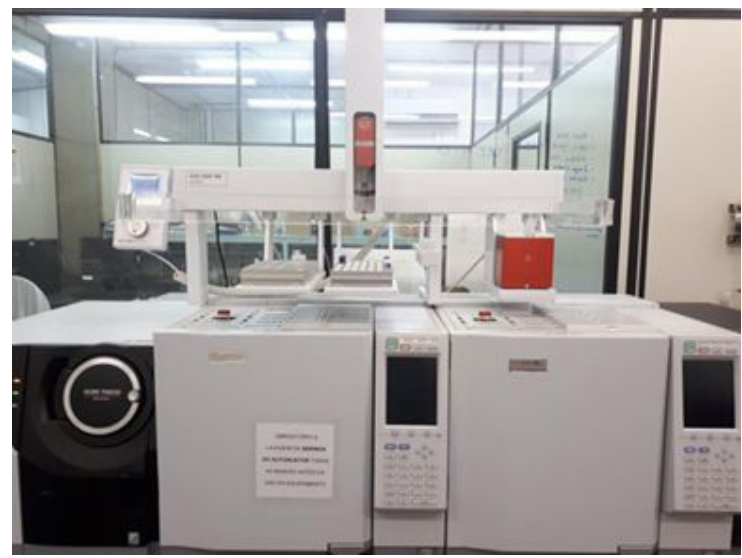

Figure 3. Chromatographic gas detector. 
Since this low content would indicate low inorganic content and high energy release.

To investigate wood species, based on the results obtained experimentally for density, contact angle and percentages of extractives, lignin and ash, analysis of variance (ANOVA) was performed, considered at the level of 5\% significance, consisting of the equivalence averages as a null hypothesis and non-equivalence (at least two) as an alternative hypothesis. By formulating the hypotheses, P-value equal to or greater than the level of significance (0.05) implies accepting the null hypothesis, refuting it otherwise.

To validate ANOVA, the normality in the distribution of the values of the properties considered and the homogeneity of the variances of the groups were investigated, with the aid of the Anderson-Darling [AD] test, considered at the $5 \%$ significance level. For the formulation of the tests, $\mathrm{P}$-value greater than $5 \%$ implies that the responses come from populations with normal distribution and that the variances of the groups are equivalent, thus validating the ANOVA model.

When ANOVA between species was found to be significant, the Tukey multiple comparison test (contrast test) was used next, making it possible to group the levels of the investigated factor and thus compare each species of tropical wood with the species of the genus Thuja.

\section{Results and Discussions}

\subsection{Evaluation of organoleptic properties of wood species}

On Tables 1 and 2, organoleptic properties of Brazilian tropical hardwoods and aromatic degrees on different uses as grilling planks, with results on hedonic scale: bad, poor, fair, good or excellent.

Physical and Chemical Results of Wood Species

Table 3 presents the mean values of physical and chemical for wood species characterization and coefficient of variation $(\mathrm{Cv})$.

Observing the values of apparent density on Table 3, Amburana cearensis and Cedrella fissilis density are close to the reference value of apparent density of Thuja plicata. For the value of contact angle, Amburana cearensis wood presented a value above $90^{\circ}$, indicating the surface is less wettable than the reference wood (Thuja plicata) $)^{20}$. Cedrella fissilis presented the lowest value of contact angle, being the surface more wettable. Also, it is important consider natural characteristics of wood, such chemical composition and surface rugosity ${ }^{21}$.

Considering the values of extractive content, Amburana cearensis wood presented an elevated value, indicating a more pronounced flavor on wood after use. Cedrella

Table 1. Organoleptic properties of Brazilian tropical hardwoods.

\begin{tabular}{ccccc}
\hline Wood Specie & Color & Texture & Taste & Grain \\
\hline Amburana cearensis & Reddish brown & Smooth & Sweet & Straight and Irregular \\
\hline Cedrella fissilis & Beige pink & Coarse & Imperceptible & Straight \\
\hline
\end{tabular}

Table 2. Smell on Different conditions.

\begin{tabular}{cccc}
\hline Wood Specie & Natural & Wet & After Heat Source \\
\hline Amburana cearensis & Excellent & Excellent & Excellent \\
\hline Cedrella fissilis & Good & Good & Good \\
\hline
\end{tabular}

Table 3. Physical and Chemical results for Wood Species.

\begin{tabular}{cccc}
\hline \multirow{2}{*}{ Properties } & & Wood Species & \\
\cline { 2 - 4 } & Amburana cearensis & Cedrella fissilis & Thuja plicata \\
\hline$\rho_{\mathrm{ap}}\left(\mathrm{g} / \mathrm{cm}^{3}\right)$ & 0.56 & 0.50 & 0.46 \\
\hline $\mathrm{Cv}(\%)$ & 4.72 & 6.98 & 68.17 \\
\hline Mean Angle & 95.81 & 43.37 & 6.10 \\
\hline Cv (\%) & 12.94 & 18.96 & 7.25 \\
\hline Extractives (\%) & 19.70 & 5.20 & 3.66 \\
\hline Cv (\%) & 0.51 & 15.04 & 0.27 \\
\hline Soluble Lignin (\%) & 0.84 & 3.27 \\
\hline Cv (\%) & 1.62 & 5.27 & 34.16 \\
\hline Insoluble Lignin (\%) & 29.25 & 0.74 \\
\hline Cv (\%) & 2.03 & 0.87 & 0.20 \\
\hline Cves (\%) $(\%)$ & 31.39 & 0.76 & 8.67 \\
\hline Holocellulose (\%) & 0.57 & 4.84 & 58.12 \\
\hline Cv (\%) & 0.97 & 63.95 & 1.29
\end{tabular}


fissilis presented a lower value compared to Thuja plicata. For chemical composition of wood species, checking lignin, ashes and holocellulose contents. Thuja plicata wood presented a value for holocellulose of $58.12 \%$, close to the obtained for Cedrella fissilis. For Amburana cearensis, the elevated value of lignin content led to minor holocellulose content, below $50 \%$ value. It is important highlight that ashes and extractives content may vary due edaphoclimatic factor ${ }^{22}$.

The result of normality test of Anderson-Darling for all analysis presented p-value above 0.05 , i.e., the results of tropical hardwoods compared with reference wood specie (Thuja plicata) presented a normal distribution, validating ANOVA results.

For the comparison of the wood species, Tables 4 to 9 displays the results for ANOVA comparing the results of tropical wood species for apparent density, contact angle, extractive, soluble lignin, insoluble lignin and ashes content.

Observing the Table 4, there is significant difference between the apparent density of Amburana cearensis and Thuja plicata. For Cedrella fissilis, the difference is not significant. For values of mean contact angle and extractive content, both wood species presented values significantly different from Thuja plicata.

Considering the values of soluble lignin, the value of Amburana cearensis were significantly differently from Thuja plicata, which not occurred for Cedrella fissilis. For insoluble lignin and ashes content, there were significantly difference between bot wood species and Thuja plicata.

The results of gas chromatography tests CG-MS are presented on Tables 10, 11 and 12 .

The results of the CG-MS assays presented in Table 10 show that, based on the hydrodistillation extraction of the species Amburana cearensis, it was possible to identify 10 compounds, with the majority compounds, of greater relative area, being, in decreasing order: Nerolidol (100\%), followed by trans-calamenene (28.48\%) and 2-Hexanol (16.21\%). Through soxhlet extraction, it was possible to identify a greater number of compounds (15), the majority of which are in decreasing order: ButylatedHydroxytoluene (100\%), Cinnamic acid (88.07\%) and Nerolidol (87.64\%). The major compound identified through headspace extraction was 1-Propyne (100\%); the seven other compounds identified had a relative area below $10 \%$.

It can also be observed that there was a difference in the identified compounds depending on the extraction technique used. Comparing the hydrodistillation and soxhlet techniques, 4 common compounds were identified: Nerolidol, Butylated Hydroxytoluen, $\alpha$-Muurolene and $\alpha$-Calacorene. In the headspace extraction, no compound in common with those of the other techniques was identified.

The results of the CG-MS assays shown in Table 11 show that, from the hydrodistillation extraction of Cedrela fissillis, it was possible to identify 12 compounds. The major compounds detected by hydrodistillation are, in decreasing order: Nerolidol (100\%), $\tau$-Cadinol (53.58\%) and $\alpha$-Cadinol (45.47\%). In soxhlet extraction, 16 compounds were identified, the major ones, in decreasing order: Nerolidol (100\%), Butylated Hydroxytoluene (48.49\%) and $\tau$-Cadinol (47.36\%). Through headspace extraction, the largest number of compounds (24) was identified, the major ones being, in decreasing order:
$\delta$-Cadinene (100\%), $\alpha$-Copaene (71.24\%) e $\alpha$ - Calacorene $(48.07 \%)$. It is worth noting that the Nerolidol compound was the major component in both hydrodistillation and soxhlet extraction, but it was not identified in headspace extraction.

Some compounds appear in all extractions. They are: $\alpha$-Copaene, $\alpha$-Calacorene, $\tau$-Cadinol and $\alpha$-Cadinol. The compounds Aromadendrene, $\delta$-Cadinene, $\alpha$-Cedrene and Cadalene are only identified in soxhlet and headspace extractions.

The results of the CG-MS tests presented in Table 12 show that, through hydrodistillation, 19 compounds were identified, the majority of them being, in decreasing order: Myrtenol (100\%), $\alpha$-terpineol (49.76\%) and Terpinen -4-ol (26.24\%). In soxhlet extraction, only seven compounds were identified, with Cuminicacid $(100 \%)$ being the majority. The other compounds presented very low relative area. It is also possible to identify the Nerolidol component in soxhlet extraction, which was not found in any of the other techniques. Finally, in headspace extraction, 25 compounds were identified, the three major ones, in decreasing order: 1-brine (100\%), Myrtenol (69\%) and Camphene (67.07\%).

The compounds identified simultaneously in all extraction techniques were: Mirtenol, $\alpha$-terpineol and carvone. Between

Table 4. Relation between apparent densities.

\begin{tabular}{cc}
\hline Wood Species & $\mathrm{p}$-value \\
\hline Thuja plicata $\mathrm{x}$ Amburana cearensis & 0.0016 \\
\hline Thuja plicata $\mathrm{x}$ Cedrella fissilis & 0.1579 \\
\hline
\end{tabular}

Table 5. Relation between mean value for contact angle for wettability.

\begin{tabular}{cc}
\hline Wood Species & p-value \\
\hline Thuja plicata $\times$ Amburana cearensis & 0.0127 \\
\hline Thuja plicata $\times$ Cedrella fissilis & 0.0207 \\
\hline
\end{tabular}

Table 6. Relation between extractive content.

\begin{tabular}{cc}
\hline Wood Species & $\mathrm{p}$-value \\
\hline Thuja plicata $\mathrm{x}$ Amburana cearensis & 0.0000 \\
\hline Thuja plicata $\mathrm{x}$ Cedrella fissilis & 0.0072 \\
\hline
\end{tabular}

Table 7. Relation between soluble lignin content.

\begin{tabular}{cc}
\hline Wood Species & $\mathrm{p}$-value \\
\hline Thuja plicata $\mathrm{x}$ Amburana cearensis & 0.0001 \\
\hline Thuja plicata $\mathrm{x}$ Cedrella fissilis & 0.0527 \\
\hline
\end{tabular}

Table 8. Relation between insoluble lignin content.

\begin{tabular}{cc}
\hline Wood Species & p-value \\
\hline Thuja plicata $\times$ Amburana cearensis & 0.0003 \\
\hline Thuja plicata $\times$ Cedrella fissilis & 0.0000 \\
\hline
\end{tabular}

Table 9. Relation between ashes content.

\begin{tabular}{cc}
\hline Wood Species & $\mathrm{p}$-value \\
\hline Thuja plicata $\mathrm{x}$ Amburana cearensis & 0.0000 \\
\hline Thuja plicata $\mathrm{x}$ Cedrella fissilis & 0.0072 \\
\hline
\end{tabular}


Table 10. Compounds detected in Amburana cearensis essential oils extracted by hydrodistillation, soxhlet and headspace.

\begin{tabular}{|c|c|c|c|c|c|}
\hline \multicolumn{2}{|c|}{ Hydrodistillation } & \multicolumn{2}{|c|}{ Soxhlet } & \multicolumn{2}{|c|}{ Headspace } \\
\hline Compound $^{\mathrm{b}}$ & I.R. $^{a}$ & Compound $^{\mathrm{b}}$ & I.R. a & Compound $^{\mathrm{b}}$ & I.R. a \\
\hline $\begin{array}{l}\text { 1,1-Dimetil-3- } \\
\text { cloropropanol }\end{array}$ & 809 & 4-metil-2-pentanol & 811 & 1-Propyne & 60 \\
\hline 2-Hexanol & 812 & hexanoic acid & 981 & 2-Nitro-1- propanol & 70 \\
\hline$\alpha$-Curcumeno & 1578 & 2-metoxi-fenol & 1091 & Ethyl Acetate & 96 \\
\hline$\alpha$-Muurolene & 1600 & Nonanal & 1107 & $\begin{array}{l}\text { 4-methyl-3- } \\
\text { Pentenal }\end{array}$ & 733 \\
\hline $\begin{array}{l}\text { Butylated } \\
\text { Hydroxytoluene }\end{array}$ & 1610 & octanoic acid & 1255 & $\begin{array}{l}\text { 4,4-Dimethyl-2- } \\
\text { cyclopenten-1- one }\end{array}$ & 777 \\
\hline$\gamma$-Muurolene & 1612 & nonanoic acid & 1378 & Octane & 798 \\
\hline trans- calamenene & 1620 & Benzodihydropyrone & 1485 & Hexanal & 803 \\
\hline$\alpha$-Calacorene & 1638 & cinnamic acid & 1537 & 1,4-cineol (SI) & 1018 \\
\hline E-Nerolidol & 1658 & $\alpha$-Muurolene & 1599 & & \\
\hline \multirow[t]{6}{*}{ Ledol } & 1700 & $\begin{array}{l}\text { Butylated } \\
\text { Hydroxytoluene }\end{array}$ & 1610 & & \\
\hline & & trans-calamenene & 1620 & & \\
\hline & & $\alpha$-Calacorene & 1638 & & \\
\hline & & Nerolidol & 1658 & & \\
\hline & & isovalinic acid & 1665 & & \\
\hline & & $\alpha$-Cubebeno & 1722 & & \\
\hline
\end{tabular}

${ }^{\mathrm{a}}$ Kovats indexes (KI) on capilar column Rtx-5 MS. ${ }^{\mathrm{b}}$ Compounds listed on evolution order on capillary column Rtx-5 MS.

Table 11. Compounds detected in Cedrella fissilis essential oils extracted by hydrodistillation, soxhlet and headspace.

\begin{tabular}{|c|c|c|c|c|c|}
\hline \multicolumn{2}{|c|}{ Hydrodistillation } & \multicolumn{2}{|c|}{ Soxhlet } & \multicolumn{2}{|c|}{ Headspace } \\
\hline Compound $^{b}$ & I.R. $^{a}$ & Compound $^{\mathrm{b}}$ & I.R. ${ }^{a}$ & Compound $^{\mathrm{b}}$ & I.R. $^{\mathrm{a}}$ \\
\hline $\begin{array}{l}\text { 1,1-dimetil-3- } \\
\text { cloropropanol }\end{array}$ & 807 & $\alpha$-Cubebene & 1466 & 1,4-Cineole & 1018 \\
\hline 4-metil-2- Pentanol & 811 & $\alpha$-Copaene & 1474 & $\delta$-EIemene & 1430 \\
\hline $\begin{array}{l}\text { 5-Metoxi-2- } \\
\text { Pentanona }\end{array}$ & 1008 & $\begin{array}{l}\text { Aromadendrene, } \\
\text { dehydro- }\end{array}$ & 1504 & $\alpha$-Cubebene & 1442 \\
\hline$\alpha$-Copaene & 1474 & $\alpha$-Bergamotene & 1528 & Y-langene & 1460 \\
\hline Naphthalene & 1620 & $\begin{array}{l}\text { Butylated } \\
\text { Hydroxytoluene }\end{array}$ & 1610 & $\alpha$-Copaene & 1471 \\
\hline$\alpha$-Calacorene & 1639 & $\delta$-Cadinene & 1618 & $\beta$-Elemene & 1488 \\
\hline Nerolidol & 1658 & $\alpha$-Calacorene & 1639 & $\begin{array}{l}\text { Aromadendrene, } \\
\text { dehydro- }\end{array}$ & 1504 \\
\hline Copaene & 1723 & Nerolidol & 1658 & $\alpha$-Santalene & 1515 \\
\hline$\tau$-Cadinol & 1736 & Ledol & - & $\alpha$-Bergamotene & 1528 \\
\hline 1-Naphthalenol & 1726 & $\begin{array}{l}\text { Caryophyllene } \\
\text { oxide }\end{array}$ & 1696 & $\alpha$-Guaiene & 1535 \\
\hline$\alpha$-Cadinol & 1748 & $\alpha$-Cedrene & 1720 & Epi- $\beta$-Santalene & 1540 \\
\hline \multirow[t]{13}{*}{ Naphthalene } & 1768 & 1-Naphthalenol & 1726 & Humulene & 1548 \\
\hline & & $\tau$-Cadinol & 1736 & Alloaromadendrene & 1556 \\
\hline & & $\delta$-Cedrol & 1738 & $\alpha$-Guaiene & 1584 \\
\hline & & $\alpha$-Cadinol & 1745 & Ledene & 1591 \\
\hline & & Cadalene & 1765 & $\alpha$-Muurolene & 1597 \\
\hline & & & & $\gamma$-Muurolene & 1609 \\
\hline & & & & $\delta$-Cadinene & 1618 \\
\hline & & & & $\alpha$-Calacorene & 1636 \\
\hline & & & & $\alpha$-Cedrene & 1720 \\
\hline & & & & $\tau$-Cadinol & 1733 \\
\hline & & & & $\delta$-Cedrol & 1738 \\
\hline & & & & $\alpha$-Cadinol & 1745 \\
\hline & & & & Cadalene & 1765 \\
\hline
\end{tabular}


Table 12. Compounds detected in Thuja plicata essential oils extracted by hydrodistillation, soxhlet and headspace.

\begin{tabular}{|c|c|c|c|c|c|}
\hline \multicolumn{2}{|c|}{ Hydrodistillation } & \multicolumn{2}{|c|}{ Soxhlet } & \multicolumn{2}{|c|}{ Headspace } \\
\hline Compound $^{\mathrm{b}}$ & I.R. $^{a}$ & Compound $^{\mathrm{b}}$ & I.R. $^{a}$ & Compound $^{\mathrm{b}}$ & I.R. $^{\mathrm{a}}$ \\
\hline $\begin{array}{l}\text { 1,1-dimethyl-3- } \\
\text { cloropropanol }\end{array}$ & 807 & 4-Terpineol & 1177 & 1-Propyne & 60 \\
\hline 2-Pentanol & 811 & p-Cymen-8-ol & 1183 & Acetonitrile & 70 \\
\hline Norbornane & 954 & $\alpha$-Terpineol & 1189 & 2-Bornene & 906 \\
\hline o-Cymene & 1029 & Myrtenol & 1297 & $\alpha$-Pinene & 937 \\
\hline $\begin{array}{l}\text { 2,7,7-trimethylbicyclo } \\
{[2.2 .1] \text { heptan-2-ol }}\end{array}$ & 1218 & Carvone & 1307 & Camphene & 951 \\
\hline \multirow[t]{2}{*}{ endo-Borneol } & 1263 & Cuminicacid & 1398 & $\beta$-Cymene & 974 \\
\hline & & Nerolidol & 1656 & & \\
\hline Terpinen-4-ol & 1274 & & & 3-Carene & 1013 \\
\hline$\alpha$-Terpineol & 1284 & & & 1,4-Cineole & 1018 \\
\hline Myrtenol & 1297 & & & o-Cymene & 1027 \\
\hline Carvone & 1309 & & & D-Limonene & 1032 \\
\hline $\begin{array}{l}\text { 2-Methyl-3- } \\
\text { phenylpropanal }\end{array}$ & 1337 & & & Eucalyptol & 1037 \\
\hline $\begin{array}{l}\text { Bicyclo[3.1.1] heptane- } \\
\text { 2-methanol, }\end{array}$ & 1340 & & & o-Isopropenyltoluene & 1086 \\
\hline 3-Caren-10-al & 1361 & & & p-Cymenene & 1094 \\
\hline $\begin{array}{l}\text { Cyclohexene- } \\
\text { carboxaldehyde }\end{array}$ & 1374 & & & $\beta$-Linalool & 1107 \\
\hline $\begin{array}{l}\text { Phenol, 2-ethyl-4,5- } \\
\text { dimethyl- }\end{array}$ & 1398 & & & $\begin{array}{l}\text { exo-2,7,7- } \\
\text { trimethylbicyclo } \\
{[2.2 .1] \text { heptan-2-ol }}\end{array}$ & 1218 \\
\hline $\begin{array}{l}\text { Benzoicacid, 2,4,5- } \\
\text { trimethyl- }\end{array}$ & 1420 & & & L-Pinocarveol & 1233 \\
\hline Acetovanillone acetate & 1426 & & & endo-Borneol & 1261 \\
\hline $\begin{array}{l}\text { Benzoicacid, 4-(1- } \\
\text { methylethyl) }\end{array}$ & 1477 & & & cis-Verbenol & 1264 \\
\hline \multirow[t]{7}{*}{ Furadane } & 1514 & & & Terpinen-4-ol & 1271 \\
\hline & & & & Ocimenol & 1281 \\
\hline & & & & $\alpha$-Terpineol & 1286 \\
\hline & & & & Myrtenol & 1294 \\
\hline & & & & Carvone & 1307 \\
\hline & & & & Isothymolmethylether & 1333 \\
\hline & & & & 3-Caren-10-al & 1359 \\
\hline
\end{tabular}

${ }^{a}$ Kovats indexes (KI) on capilar column Rtx-5 MS. ${ }^{\mathrm{b}}$ Compounds listed on evolution order on capillary column Rtx-5 MS.

hydrodistillation and headspace, two more common compounds were found: Terpinen-4-ol and o-Cymene.

It is important highlight that different chemical compounds were found for each extraction method (hydrodestillation, soxlet and headspace) due to effectiveness of each method. Sohxlet and hydrodistillation are more similar in the essential oil extraction method, which differentiates them from headspace. Thus, the capillary column ends up identifying different compounds.

One component present in all wood species is Nerolidol. This substance is allowed by the United States Food and Drugs Administration (FDA) to be used on food industry as food flavoring agent. Then, it enhances the possibility the use of tropical wood species as grilling planks on food industry, improving dishes preparation ${ }^{23-25}$.

Also, otherwise Thuja plicata, Amburana cearensis and Cedrella fissilis did not presented, according chemical analysis, toxic volatile chemical compounds such Thujone, toxic for human being even at low levels ${ }^{9}$, enabling their use as grilling planks, with similar apparent density of a well-known wood specie already used for grilling planks and satisfactory organoleptic properties for use on planks. Also, a lower apparent density for Amburana cearensis and Cedrella fissilis contributes a good impregnation process during plank manufacture and lower weight, reducing costs along productive process and transportation.

It is important highlight this research is original, with no precedent work treating the production of grilling planks using tropical hardwoods, analyzing organoleptic and chemical properties.

\section{Conclusions}

The results of the present research enable us to conclude:

- Apparent density of Amburana cearensis and Cedrella fissilis were close to the reference value of Thuja plicata 
wood specie, being interesting the wood species with lower apparent density;

- Chemical analysis indicated the possibility the use of tropical hardwoods for grilling planks production, with elevated amount of extractive content, important for organoleptic properties, such taste and smell;

- From gas chromatography results, the presence of Nerolidol, used as flavoring agent on several foods, on all wood species and the nonexistence of Thujone chemical compound, toxic for humans, and organoleptic properties were satisfactory, indicating the possibility of use of Amburana cearensis and Cedrella fissilis wood species for grilling plank production.

\section{References}

1. Christoforo AL, Aquino VBM, Wolenski ARV, Araujo VAD, Lahr FAR. Evaluation of the Peltophorum vogelianum Benth. wood species for structural use. Eng Agric. 2019;39(6):763-8. http:// dx.doi.org/10.1590/1809-4430-eng.agric.v39n6p763-768/2019.

2. Lahr FAR, Arroyo FN, Almeida TH, Almeida FM Fo, Mendes IS, Christoforo AL. Full characterization of Erisma uncinatum Warm Wood Specie. Int J Mater Eng. 2016;6(5):147-50. http:// dx.doi.org/10.5923/j.ijme.20160605.01.

3. Sthapit E. Memories of gastronomic experiences, savoured positive emotions and savouring processes. Scand J Hosp Tour. 2019;19(2):115-39. http://dx.doi.org/10.1080/15022250.2017 .1402702 .

4. Bilal M, Iqbal HMN. State-of-the-art strategies and applied perspectives of enzyme biocatalysis in food sector: current status and future trends. Crit Rev Food Sci Nutr. 2020;60(12):205266. http://dx.doi.org/10.1080/10408398.2019.1627284.

5. Soares JF, Prá VD, Kempka AP, Prestes RC, Tres MV, Kuhn $\mathrm{RC}$, et al. Cellulases for food applications. In: Gupta VK, editor. New and future developments in microbial biotechnology and bioengineering. Amsterdam: Elsevier; 2016. p. 201-8. http:// dx.doi.org/10.1016/B978-0-444-63507-5.00018-6.

6. Ben Akacha N, Gargouri M. Microbial and enzymatic technologies used for the production of natural aroma compounds: synthesis, recovery modeling, and bioprocesses. Food Bioprod Process. 2015;94:675-706. http://dx.doi.org/10.1016/j.fbp.2014.09.011.

7. Ledesma E, Rendueles M, Díaz M. Smoked food. In: Larroche C, Sanroman M, Du G, Pandey A, editors. Current developments in biotechnology and bioengineering. Amsterdam: Elsevier; 2017. p. 201-43. http://dx.doi.org/10.1016/B978-0-444-63666-9.00008-X.

8. Zoschke H. Grillen \& BBQ, Sonstiges [Internet]. 2016 [cited 2021 Jan 6]. Available from: http://pepperworld.com/mit-dergrillplanke-grillen-wie-die-profis-teil-1

9. European Commission. Opinion of the Scientific Committee on Food on Thujone [Internet]. Brussels: European Comission; 2002. [cited 2021 Jan 6]. Available from: http://ec.europa.eu/ food/fs/sc/scf/out120_en.pdf

10. Beech E, Rivers M, Oldfield S, Smith PP. GlobalTreeSearch: the first complete global database of tree species and country distributions. J Sustain For. 2017;36(5):454-89. http://dx.doi. org/10.1080/10549811.2017.1310049.

11. IBÁ: Indústria Brasileira de Árvores. Relatório IBÁ [Internet]. Brasília; 2017. 80 p. [cited 2021 Jan 6]. Available from: http:// iba.org/images/shared/Biblioteca/IBA_RelatorioAnual2017.pdf

12. Marquéz MDR. Plantas aromáticas: tratado de aromaterapia cientifica. 1. ed. Buenos Aires: Kier; 2004. 224 p.

13. Lorenzi H. Árvores brasileiras: manual de identificação de plantas arbóreas nativas do Brasil. 2. ed. Nova Odessa: Plantarum; 1998.

14. ABNT: Associação Brasileira de Normas Técnicas . NBR 7190: projeto de estruturas de madeira. Rio de Janeiro: ABNT; 1997. $107 \mathrm{p}$.

15. Zenid GJ. Identificação e grupamento das madeiras serradas empregadas na construção civil habitacional na cidade de São Paulo [dissertação]. Piracicaba: Universidade de São Paulo; 2019 [cited 2021 Jan 6]. Available from: https://teses.usp.br/ teses/disponiveis/11/11149/tde-20191218-140415/

16. TAPPI: Technical Association of the Pulp and Paper Industry. Test methods: T $264 \mathrm{~cm}$ - 97: preparation of wood for chemical analysis. Atlanta: TAPPI Press; 1997.

17. TAPPI: Technical Association of the Pulp and Paper Industry. TAPPI test methods: T $257 \mathrm{~cm}-85$ : sampling and preparing wood for analysis. Atlanta: TAPPI Press; 1985.

18. Gomide JL, Memuner BJ. Determinação do teor de lignina em material lenhoso: método Klason modificado. O Papel. 1986;47(8):36-8.

19. Tjeerdsma BF, Militz H. Chemical changes in hydrothermal treated wood: FTIR analysis of combined hydrothermal and dry heat-treated wood. Holz Roh- Werkst. 2005;63(2):102-11. http://dx.doi.org/10.1007/s00107-004-0532-8.

20. Wu L, Baghdachi J, editors. Functional polymer coatings. 1st ed. Hoboken: John Wiley \& Sons; 2015. 352 p. http://dx.doi. org/10.1002/9781118883051.

21. Adamson AW, Gast AP. Physical chemistry of surfaces. Hoboken: John Wiley \& Sons; 1997. 808 p.

22. Zau MDL, Vasconcelos RP, Giacon VM, Lahr FAR. Avaliação das propriedades química, física e mecânica de painéis aglomerados produzidos com resíduo de madeira da Amazônia - Cumaru (Dipteryx Odorata) e resina poliuretana à base de óleo de mamona. Polímeros. 2014;24(6):726-32. http://dx.doi. org/10.1590/0104-1428.1594.

23. Chan WK, Tan LTH, Chan KG, Lee LH, Goh BH. Nerolidol: a sesquiterpene alcohol with multi-faceted pharmacological and biological activities. Molecules. 2016;21(5):529. http://dx.doi. org $/ 10.3390 /$ molecules21050529.

24. Ušjak L, Petrović S, Drobac M, Soković M, Stanojković T, Ćirić A, et al. Edible wild plant Heracleum pyrenaicum subsp. orsinii as a potential new source of bioactive essential oils. J Food Sci Technol. 2017;54(8):2193-202. http://dx.doi.org/10.1007/ s13197-017-2610-z.

25. Azzi J, Auezova L, Danjou PE, Fourmentin S, Greige-Gerges H. First evaluation of drug-in-cyclodextrin-in-liposomes as an encapsulating system for nerolidol. Food Chem. 2018;255:399404. http://dx.doi.org/10.1016/j.foodchem.2018.02.055. 